\title{
SISTEM PAKAR DIAGNOSA PENYAKIT PERIODONTAL MENGGUNAKAN METODE DEMPSTER - SHAFER
}

\author{
Muhammad Aufa Ridwan \\ Fakultas Teknik, Program Studi Teknik Informatika \\ Universitas Samudra \\ Email: $\underline{\text { m.aufa78@gmail.com }}$ \\ Arief Maulana \\ Fakultas Teknik, Program Studi Teknik Informatika \\ Universitas Samudra \\ Email: mamangmaulana120@gmail.com \\ Aulia Rahman Syahputera \\ Fakultas Teknik, Program Studi Teknik Informatika \\ Universitas Samudra \\ Email: arsy.jr@gmail.com \\ Mudhi Ulfani \\ Fakultas Teknik, Program Studi Teknik Informatika \\ Universitas Samudra \\ Email: mudhiulfanii@gmail.com
}

\begin{abstract}
ABSTRAK
Penyakit periodontal atau periodontal pathology, merupakan penyakit yang menyebabkan terlepasnya gigi akibat reaksi dari bakteri yang menghasilkan kerusakan progresif pada jaringan penunjang gigi. Menurut hasil riset kesehatan dasar Indonesia tahun 2013, sebesar 25,9\% penduduk Indonesia mempunyai masalah kesehatan jaringan periodontal. Masalah yang dihadapi adalah inimnya pengetahuan serta terbatasnya sumber informasi mengenai kesehatan jaringan periodontal menyebabkan kesadaran masyarakat untuk menjaga kesehatan gigi dan mulut masih rendah. Oleh karena itu, maka perlu adanya inovasi yang mampu melakukan konsultasi dengan mudah hanya dengan memberikan potongan informasi tentang penyakit periodontal. Inovasi tersebut memanfaatkan pengetahuan yang dimiliki oleh pakar agar dapat menghasilkan diagnosa yang sesuai dengan pemeriksaan yang dilakukan secara langsung. Metode yang digunakan dalam penelitian ini adalah metode Dempster - Shafer yaitu metode representasi, kombinasi dan propogasi ketidakpastian, dimana teori ini memiliki beberapa karakteristik yang secara intuitif sesuai dengan cara berfikir seorang pakar, namun dasar matematika yang kuat. Dempster-Shafer digunakan untuk mendapatkan persentase tertinggi kemungkinan terjadinya suatu penyakit berdasarkan informasi gejala yang diberikan. Hasil penelitian menunjukkan bahwa penentuan penyakit sangat dipengaruhi oleh nilai belief serta data aturan yang diberikan oleh pakar. Pemanfaatan metode Dempster - Shafer telah berhasil melakukan diagnose penyakit dengan nilai akurasi sebesar 92,86\% dari subjek penelitian sebanyak 14 orang pasien klinik gigi dan mulut Rumah Sakit Umum Daerah Langsa.
\end{abstract}

Kata kunci: sistem pakar, demspter - shafer, penyakit periodontal

\section{ABSTRACT}

Periodontal disease is a disease that causes tooth loss due to inflammation from bacteria that results in progressive damage to the supporting tissues of the teeth. According to the results of Indonesia's basic health research in 2013, 25.9\% of Indonesia's population has periodontal tissue health problems. The problem faced is the lack of knowledge and the limited source of information 
about the health of periodontal tissues, causing public awareness to maintain oral health is still low. Therefore, it is necessary to have innovations are capable to carry out consultations easily without having to be given clear information about periodontal disease. The innovation utilizes the knowledge possessed by experts in order to produce a diagnosis that is consistent with the examination carried out directly. The method used in this study is the Dempster-Shafer method, which is a method of representation, combination and uncertainty propogation, where this theory has several characteristics that are instutitively in accordance with the way of thinking of an expert, but with a strong mathematical basis. Dempster - Shafers are used to get the highest percentage of the likelihood of an illness based on the symptom information provided. The results showed that the determination of the disease was strongly influenced by the value of belief as well as rule data provided by experts. Utilization of the Dempster-Shafer method has successfully diagnosed the disease with an accuracy value of $92.86 \%$ of the study subjects as many as 14 dental and oral clinic patients at the Rumah Sakit Umum Daerah Langsa.

Keywords: expert system, demspter - shafer, periodontal disease

\section{PENDAHULUAN}

Hampir setiap orang pernah mengalami gangguan kesehatan jaringan periodontal, baik berupa gangguan gigi berlubang maupun gangguan jaringan penyangga gigi. Upaya pemeliharaan plak gigi untuk kesehatan jaringan periodontal yang masih sangat rendah menjadi pemicu banyak terjadinya gangguan penyakit pada jaringan periodontal.

Menurut hasil riset kesehatan dasar Indonesia tahun 2013, sebesar 25,9\% penduduk Indonesia mempunyai masalah kesehatan jaringan periodontal. Diantara mereka, terdapat $31,1 \%$ yang menerima perawatan, sementara 68,9\% lainnya tidak melakukan perawatan (4). Riset kesehatan dasar Indonesia dilakukan pada seluruh fasilitas kesehatan yang ada di Indonesia, salah satunya Rumah Sakit Umum Daerah Langsa.

Penyakit periodontal atau periodontal pathology, merupakan penyakit yang menyebabkan terlepasnya gigi akibat inflamasi dari bakteri yang menghasilkan kerusakan progresif pada jaringan penunjang gigi (7). Penyakit periodontal di masyarakat mempunyai dampak yang luas, yaitu gangguan pada kualitas hidup antara lain keterbatasan fungsi gigi (sulit mengunyah, makanan tersangkut, nafas bau, pencernaan terganggu), disabilitas fisik (diet tidak memuaskan, menghindari makanan tertentu, tidak bisa menyikat gigi dengan baik), keluhan rasa sakit setiap mengunyah makanan, ngilu, sakit kepala, sakit di rahang), ketidaknyamanan psikis (merasa rendah diri, sangat menderita, khawatir), dan disabilitas psikis (tidur terganggu, sulit berkonsentrasi, merasa malu) (10).

Perkembangan dunia teknologi informasi telah banyak mengalami perubahan yang pesat, seiring dengan kebutuhan manusia akan teknologi informasi. Hal ini mendorong para ahli untuk mengembangkan komputer agar dapat membantu kerja manusia. Salah satu ilmu komputer yang dapat membantu mengembangkan komputer untuk membantu kerja manusia adalah sistem pakar (Expert System).

Kurangnya informasi mengenai penyakit yang sedang diderita, rasa malu dan tertutup untuk berkonsultasi secara langsung mengenai kesehatan jaringan periodontal menyebabkan penyakit semakin berkembang. Oleh karena itu, maka perlu adanya inovasi yang mampu melakukan konsultasi dengan mudah tanpa harus diberikan informasi yang jelas tentang penyakit periodontal.

Implementasi sistem pakar dapat digunakan diberbagai bidang salah satunya bidang kesehatan. Ada beberapa metode yang dapat diterapkan pada sistem pakar. Dalam penelitiannya, Hamidi menyatakan bahwa "Metode Dempster - Shafer mendiagnosis penyakit kelinci di kota Pontianak lebih baik dibandingkan dengan metode Certainty Factor. Tingkat keakuratan hasil diagnosis sistem pakar dengan metode Certainty Factor adalah 80\%, sedangkan hasil diagnosis sistem pakar dengan metode Dempster - Shafer adalah 85\%" (2).

Metode Dempster - Shafer pertama kali diperkenalkan oleh Dempster yang melakukan percobaan model ketidakpastian dengan range probabilitas sebagai probabilitas tunggal. Kemudian pada tahun 1976 Shafer mempublikasikan teori Dempster tersebut pada sebuah buku yang berjudul 
Mathematical Theory of Evidence. Secara umum teori Dempster - Shafer ditulis dalam suatu interval [Belief, Plausibility]. Belief (Bel) adalah ukuran kekuatan evidence dalam mendukung suatu himpunan proposisi. Jika bernilai 0 (nol) maka mengindikasikan bahwa tidak ada kepastian (6).

\section{METODOLOGI PENELITIAN}

\subsection{Analisis Kebutuhan Sistem}

Sebelum melakukan pengembangan sistem maka tahap pertama yang harus dilakukan adalah menganalisis kebutuhan sistem dari sisi perangkat lunak (software) dan kebutuhan perangkat keras (hardware). Kebutuhan sistem tersebut adalah sebagai berikut :

Tabel 1. Kebutuhan Sistem

\begin{tabular}{ccllc}
\hline No & Perangkat & \multicolumn{1}{c}{ Spesifikasi } & \multicolumn{1}{c}{ Kegunaan } & Jumlah \\
\hline 1 & Laptop & $\begin{array}{l}\text { Intel Core i7, } \\
\text { Ram 4 GB }\end{array}$ & $\begin{array}{l}\text { Perangkat pembuatan dan } \\
\text { pengujian aplikasi. }\end{array}$ & 1 \\
\hline 2 & MySQL & MySQL 5.5 & Database server & 1 \\
\hline 3 & PHP & PHP 5.6 & $\begin{array}{l}\text { Bahasa pemrograman yang } \\
\text { digunakan }\end{array}$ & 1 \\
\hline 4 & Web Server & Apache & $\begin{array}{l}\text { Agar script php dapat berjalan } \\
\text { di web server }\end{array}$ & 1 \\
\hline
\end{tabular}

\subsection{Pengumpulan Data}

Pengumpulan data dalam penelitian ini dilakukan di Rumah Sakit Umum Daerah Langsa yang terdapat di Kota Langsa menggunakan data yang didapat langsung dari dokter spesialis bedah mulut dengan melakukan Studi Pustaka, Dokumentasi, dan Diskusi Bebas. Dari hasil pengumpulan data diperoleh pengetahuan tentang gejala, penyakit, solusi serta nilai belief.

\subsection{Perancangan Sistem}

\subsubsection{Diagram Alur Konsultasi}

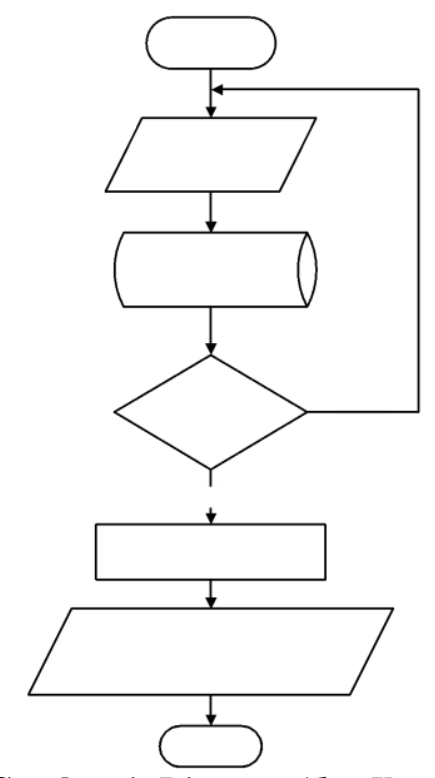

Gambar 1. Diagram Alur Konsultasi 
Diagram alur konsultasi merupakan alur yang digunakan pengguna dalam berinteraksi dengan sistem. Pada tahap awal, seorang pengguna diwajibkan untuk memilih gejala yang tersedia pada sistem berdasarkan keluhan yang sedang dialami. Pemilihan gejala ini memberikan kebebasan kepada pengguna untuk memilih lebih dari 1 (satu) gejala dalam melakukan konsultasi. Gejala yang telah dipilih oleh pengguna selanjutnya akan tersimpan pada basis pengetahuan sebagai pembelajaran sistem. Pada tahap ini sistem akan melakukan pencocokan dengan melihat pilihan gejala yang ada, apabila gejala yang dipilih sudah memenuhi ketentuan yaitu lebih dari 1 , maka sistem akan dilanjutkan dengan melakukan perhitungan menggunakan metode Dempster Shafer. Namun sebaliknya, apabila ketentuan gejala belum atau tidak terpenuhi maka pengguna diwajibkan untuk memilih gejala kembali. Setelah melalui proses perhitungan dengan metode dempster shafer, sistem akan menampilkan hasil diagnosa beserta nilai kepercayaan yang ditemukan.

\subsubsection{Metode Demspter - Shafer}

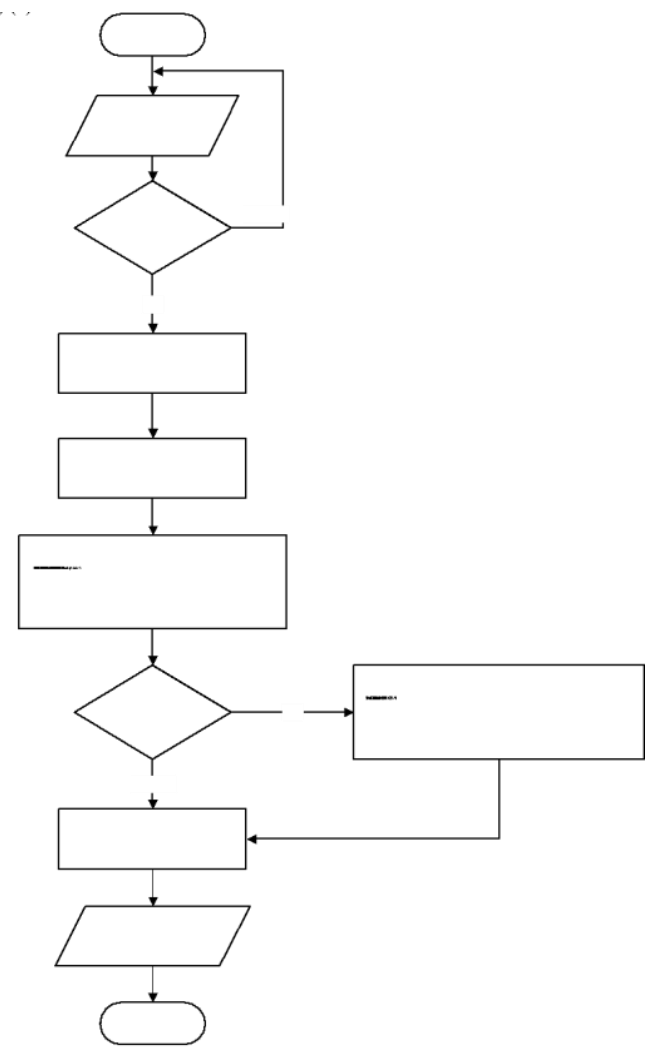

Gambar 2. Metode Dempster - Shafer

Proses diagnosa membutuhkan data masukan berupa gejala dari pasien. Pada tahap ini, sistem akan melakukan pengujian apakah gejala yang dipilih sudah memenuhi ketentuan, apabila tidak lebih dari 1 maka pasien diharuskan untuk memilih gejala hingga lebih dari 1. Apabila pada proses pemilihan gejala, pasien memilih 2 gejala atau lebih, maka dilakukan perhitungan untuk mencari kombinasi dari nilai gejala pertama atau $\mathrm{m} 1(\mathrm{X})$ dan gejala kedua atau $\mathrm{m} 2(\mathrm{Y})$. Kombinasi dari $\mathrm{m} 1(\mathrm{X})$ dan $\mathrm{m} 2(\mathrm{Y})$ menghasilkan nilai dari $\mathrm{m} 3(\mathrm{Z})$. Perhitungan dilakukan dengan menggunakan persamaan:

$$
m 3(Z)=\frac{\sum_{X \cap Y=Z} m 1(X) \cdot m 2(Y)}{1-\sum_{X \cap Y=\theta} m 1(X) \cdot m 2(Y)}
$$


Keterangan:

$m_{3}(Z) m_{3}(Z)$

(Z)

$$
m_{1}(X) m_{1}(X)
$$

$(\mathrm{X})$
: mass function dari evidence

: mass function dari evidence

$m_{2}(Y) m_{2}(Y)$ : mass function dari evidence $(\mathrm{Y})$

Pada kondisi tertentu seperti gejala yang dipilih berjumlah 3 atau lebih, sistem akan menentukan nilai dari mass function baru dengan persamaan:

$$
m_{n}(Z)=\frac{\sum_{X \cap Y=Z} m_{n}(X) \cdot m_{n}(Y)}{1-\sum_{X \cap Y=\theta} m_{n}(X) \cdot m_{n}(Y)}
$$

Keterangan:

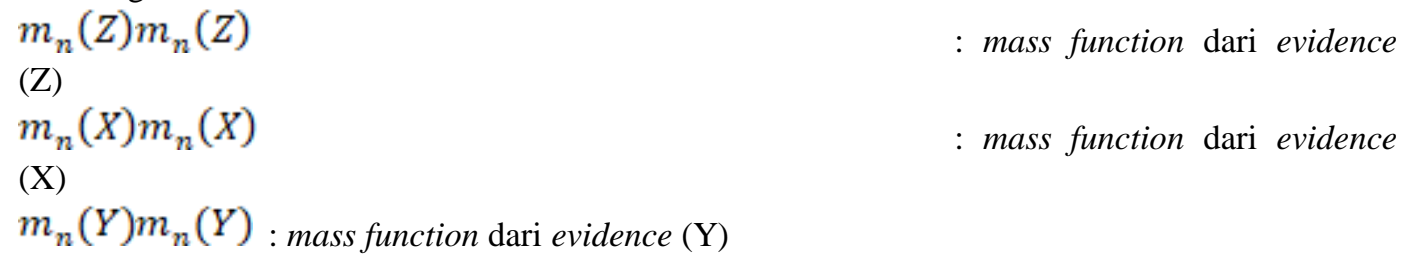

: mass function dari evidence

: mass function dari evidence

Setelah melakukan perhitungan menggunakan persamaan tersebut, didapatkan nilai kepercayaan gejala terhadap penyakit berdasarkan basis pengetahuan yang ada. Dalam beberapa kasus, hasil perhitungan memungkinkan sistem mendapatkan hasil lebih dari 1 jenis penyakit sesuai dengan gejala yang dipilih, namun sistem akan memilih penyakit yang memiliki nilai kemungkinan yang tertinggi dan akan mengabaikan nilai lainnya.

\subsubsection{Diagram Konteks}

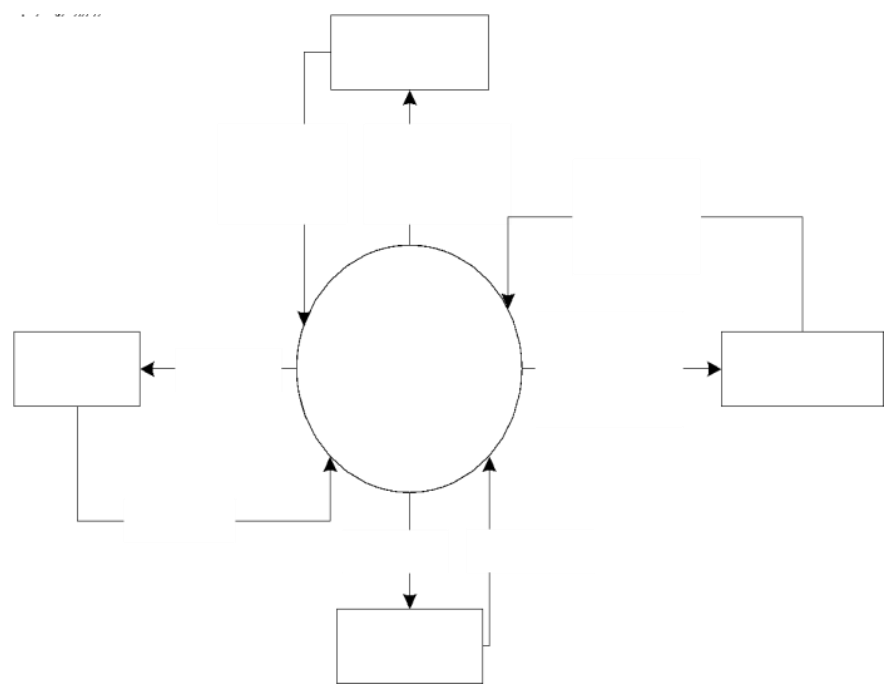

Gambar 3. Diagram Konteks

Diagram konteks menggambarkan sebuah sistem yang telah ada secara keseluruhan mulai dari interaksi antara administrator dengan sistem, pakar dengan sistem, pasien dengan sistem, sampai interaksi antara seorang dokter dengan sistem. 


\subsubsection{Entity Relationship Diagram (ERD)}

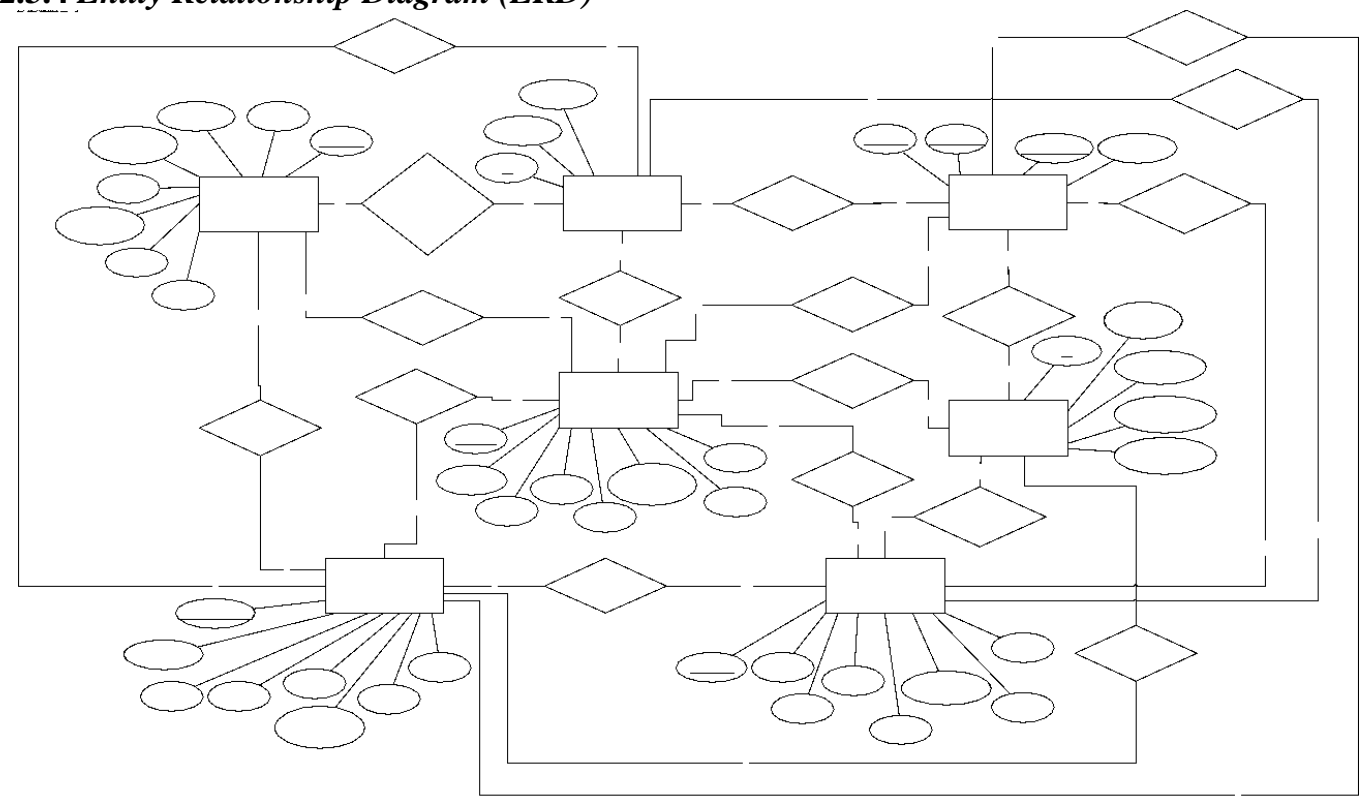

Gambar 4. Entity Relationship Diagram (ERD)

Entity Relationship Diagram menggambarkan hubungan antar entitas pada sistem pakar diagnosa penyakit periodontal.

\subsubsection{Basis Pengetahuan}

Tabel 2. Data Gejala

\begin{tabular}{cl}
$\begin{array}{c}\text { Kode } \\
\text { Gejala }\end{array}$ & \\
\hline G001 & Bau mulut tak sedap \\
\hline G002 & Gusi bengkak \\
\hline G003 & Gusi mudah berdarah saat menyikat gigi \\
\hline G004 & Gusi berwarna merah kehitaman \\
\hline G005 & Gusi mengalami inflamasi dan peka jika disentu \\
\hline G006 & Gusi terlepas \\
\hline G007 & Gigi terlihat lebih panjang \\
\hline G008 & Gigi depan mulai bergeser \\
\hline G009 & Abses pada gusi mulai terbentuk \\
\hline G010 & Gigi goyang \\
\hline G011 & Terbentuk poket antara gigi dan gusi \\
\hline G012 & Luka berwarna putih pada lidah, pipi bagian dalam, langit - langit, gusi dan \\
\hline amandel
\end{tabular}




\begin{tabular}{ll}
\hline G020 & Pembengkakan kelenjar getah bening di leher \\
\hline G021 & Terasa nyeri saat mengunyah makanan \\
\hline G022 & Terasa nyeri pada gusi \\
\hline G023 & Ujung gusi mengalami pengikisan \\
\hline G024 & Bibir terasa kering \\
\hline G025 & Luka terbuka lebar pada mulut \\
\hline G026 & Gusi berwarna merah \\
\hline
\end{tabular}

Data gejala berisikan informasi gejala yang menjadi ciri atau tanda terjadinya suatu penyakit

Tabel 3. Data Penyakit

\begin{tabular}{|c|c|c|c|}
\hline $\begin{array}{c}\text { Kode } \\
\text { Penyakit }\end{array}$ & Nama Penyakit & Definisi Penyakit & Solusi \\
\hline \multirow[t]{2}{*}{ P001 } & Gingivitis & $\begin{array}{l}\text { Gingivitis (radang gusi) } \\
\text { adalah penyakit akibat infeksi } \\
\text { bakteri yang menyebabkan gusi } \\
\text { meradang hingga merah dan } \\
\text { membengkak. kondisi gingivitis } \\
\text { ditimbulkan oleh plak, perubahan } \\
\text { gingiva juga dideteksi selama } \\
\text { periode ketidakseimbangan } \\
\text { hormonal dan penyakit sistemik, } \\
\text { atau sebagai efek samping obat. }\end{array}$ & $\begin{array}{l}\text { Menjaga kebersihan } \\
\text { mulut seperti rajin } \\
\text { menyikat gigi, } \\
\text { gunakan sikat yang } \\
\text { lembut dengan kepala } \\
\text { berujung kecil, } \\
\text { menggunakan pasta } \\
\text { gigi yang } \\
\text { mengandung } \\
\text { fluoride, melakukan } \\
\text { flossing setelah sikat } \\
\text { gigi. }\end{array}$ \\
\hline & & & $\begin{array}{l}\text { Melakukan scalling } \\
\text { gigi, root planning, } \\
\text { atau curettage yang } \\
\text { disesuaikan dengan } \\
\text { tingkat keparahan }\end{array}$ \\
\hline \multirow[t]{3}{*}{ P002 } & Periodontitis & $\begin{array}{l}\text { Penyakit peradangan jaringan } \\
\text { pendukung gigi yang disebabkan } \\
\text { oleh kelompok mikroorganisme } \\
\text { tertentu, yang mengakibatkan } \\
\text { penghancuran progresif } \\
\text { ligamentum periodontal dan } \\
\text { tulang alveolar, dengan } \\
\text { pembentukan poket, resesi, atau } \\
\text { keduanya. }\end{array}$ & $\begin{array}{l}\text { Menjaga kesehatan } \\
\text { gigi agar terbebas } \\
\text { dari bakteri. } \\
\text { Gosoklah gigi setiap } \\
\text { selesai makan atau } 2 \\
\text { kali sehari }\end{array}$ \\
\hline & & & $\begin{array}{l}\text { Melakukan scalling } \\
\text { atau pembersihan } \\
\text { karang gigi }\end{array}$ \\
\hline & & & $\begin{array}{l}\text { Melakukan root } \\
\text { planing untuk } \\
\text { membersihkan dan } \\
\text { mencegah } \\
\text { penumpukan bakteri }\end{array}$ \\
\hline P003 & Kandidiasis & $\begin{array}{l}\text { Kandidiasis adalah infeksi jamur } \\
\text { yang disebabkan oleh jenis jamur } \\
\text { yaitu Candida, atau Candida } \\
\text { albicans. Kandidiasis dapat }\end{array}$ & $\begin{array}{l}\text { Lakukan kebersihan } \\
\text { gigi yang baik. Sikat } \\
\text { gigi setidaknya } 2 \text { kali } \\
\text { sehari dan floss } 1 \text { kali } \\
\text { sehari. Ganti sikat }\end{array}$ \\
\hline
\end{tabular}


mempengaruhi area kelamin, gigi dengan sering mulut, kulit, dan darah sampai infeksi pulih.

Jangan bergantian

sikat gigi.

Kumur dengan air garam hangat.

Larutkan $1 / 2$ sendok teh garam $(2,5 \mathrm{~mL})$ dengan 1 cup (235 $\mathrm{mL}$ ) air hangat. Kumur dan buang larutan, jangan ditelan.

Gunakan nursing pads

Jaga kadar gula Hindari potensial iritan

\begin{tabular}{|c|c|c|c|}
\hline P004 & Abses Periodontal & $\begin{array}{l}\text { Kumpulan nanah yang } \\
\text { terlokalisasi (yaitu abses) di dalam } \\
\text { jaringan periodonsium. Abses } \\
\text { periodontal terjadi di samping } \\
\text { gigi, dan berbeda dari abses } \\
\text { periapikal yang lebih umum, yang } \\
\text { mewakili penyebaran infeksi dari } \\
\text { gigi mati (yaitu yang telah } \\
\text { mengalami nekrosis pulpa). }\end{array}$ & $\begin{array}{l}\text { Melakukan scalling } \\
\text { gigi, root planing, } \\
\text { atau curettage yang } \\
\text { disesuaikan dengan } \\
\text { tingkat keparahan }\end{array}$ \\
\hline & & & $\begin{array}{l}\text { Pemberian antibiotik } \\
\text { atau anti jamur }\end{array}$ \\
\hline \multirow[t]{3}{*}{ P005 } & Abses Periapikal & $\begin{array}{l}\text { Kumpulan nanah yang } \\
\text { terlokalisasi (yaitu abses) di dalam } \\
\text { jaringan periodonsium. Abses } \\
\text { periapikal terjadi di ujung gigi. }\end{array}$ & $\begin{array}{l}\text { Melakukan bedah } \\
\text { mulut }\end{array}$ \\
\hline & & & $\begin{array}{l}\text { Pengobatan saluran } \\
\text { akur }\end{array}$ \\
\hline & & & $\begin{array}{l}\text { Mencabut pulpa yang } \\
\text { mengeluarkan nanah }\end{array}$ \\
\hline P006 & Gingivostomatitis & $\begin{array}{l}\text { Gingivostomatitis adalah } \\
\text { permasalahan pada mulut yang } \\
\text { umum terjadi. Penyakit ini } \\
\text { biasanya ditandai dengan } \\
\text { pembengkakan dan luka di mulut } \\
\text { serta gusi. }\end{array}$ & $\begin{array}{l}\text { Pemberian antibiotik } \\
\text { atau anti jamur }\end{array}$ \\
\hline
\end{tabular}

Data penyakit berisikan jenis - jenis penyakit yang termasuk ke dalam kategori penyakit periodontal.

Tabel 4. Data Aturan

\begin{tabular}{ccc}
\hline Kode Aturan & Kode Gejala & Kode Penyakit \\
\hline 1 & G001 & P001 \\
\hline 2 & G002 & P001 \\
\hline 3 & G003 & P001 \\
\hline
\end{tabular}




\begin{tabular}{|c|c|c|}
\hline 4 & G004 & P001 \\
\hline 5 & G005 & P001 \\
\hline 6 & G006 & $\mathrm{P} 002$ \\
\hline 7 & G001 & $\mathrm{P} 002$ \\
\hline 8 & G005 & $\mathrm{P} 002$ \\
\hline 9 & G007 & $\mathrm{P} 002$ \\
\hline 10 & G008 & P002 \\
\hline 11 & G009 & $\mathrm{P} 002$ \\
\hline 12 & G010 & $\mathrm{P} 002$ \\
\hline 13 & G011 & $\mathrm{P} 002$ \\
\hline 14 & G012 & P003 \\
\hline 15 & G013 & $\mathrm{P} 003$ \\
\hline 16 & G014 & P003 \\
\hline 17 & G015 & $\mathrm{P} 003$ \\
\hline 18 & G016 & $\mathrm{P} 003$ \\
\hline 19 & G017 & P004 \\
\hline 20 & G002 & P004 \\
\hline 21 & G014 & $\mathrm{P} 004$ \\
\hline 22 & G018 & P004 \\
\hline 23 & G014 & P005 \\
\hline 24 & G019 & $\mathrm{P} 005$ \\
\hline 25 & G020 & P005 \\
\hline 26 & G021 & P005 \\
\hline 27 & G022 & $\mathrm{P} 005$ \\
\hline 28 & G023 & P006 \\
\hline 29 & G024 & P006 \\
\hline 30 & G025 & P006 \\
\hline 31 & G026 & P006 \\
\hline 32 & G012 & P006 \\
\hline
\end{tabular}

\section{HASIL DAN PEMBAHASAN}

\subsection{Hasil Impelentasi Sistem}

Implementasi sistem adalah tahap penerapan serta pengembangan sistem berdasarkan pada rancangan yang telah dibuat. Hasil implementasi sistem menampilkan halaman - halaman maupun modul - modul aplikasi yang telah dibuat. 


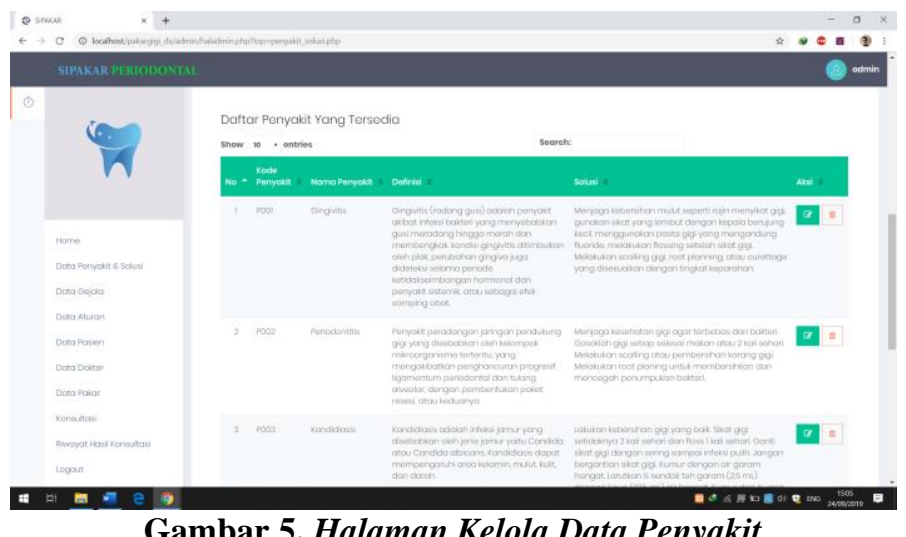

Halaman kelola data penyakit merupakan halaman yang digunakan untuk menambah, mengedit, menghapus data penyakit yang dibutuhkan sistem.

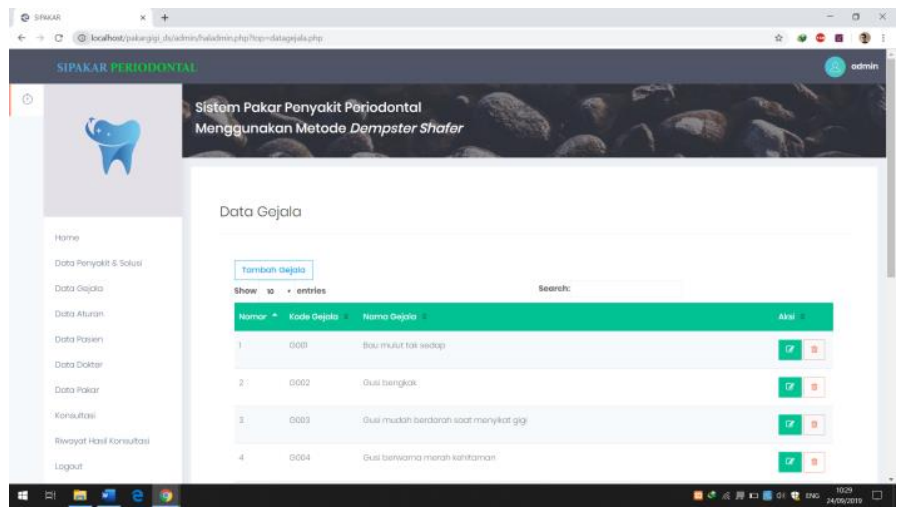

Gambar 6. Halaman Kelola Data Gejala

Halaman ini akan menampilkan tabel seluruh data gejala yang telah ada pada database sistem. Pada sistem pakar diagnosa penyakit periodontal yang telah dibuat, terdapat 26 data gejala

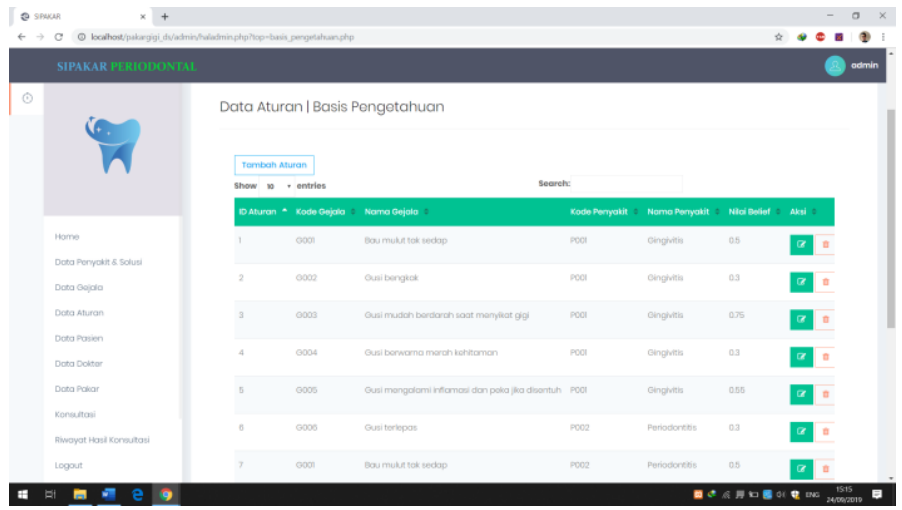

Gambar 7. Halaman Kelola Data Aturan

Halaman kelola data aturan merupakan halaman untuk menambah, menghapus, mengedit basis pengetahuan aturan yang menghubungkan antara data gejala dengan data penyakit. 


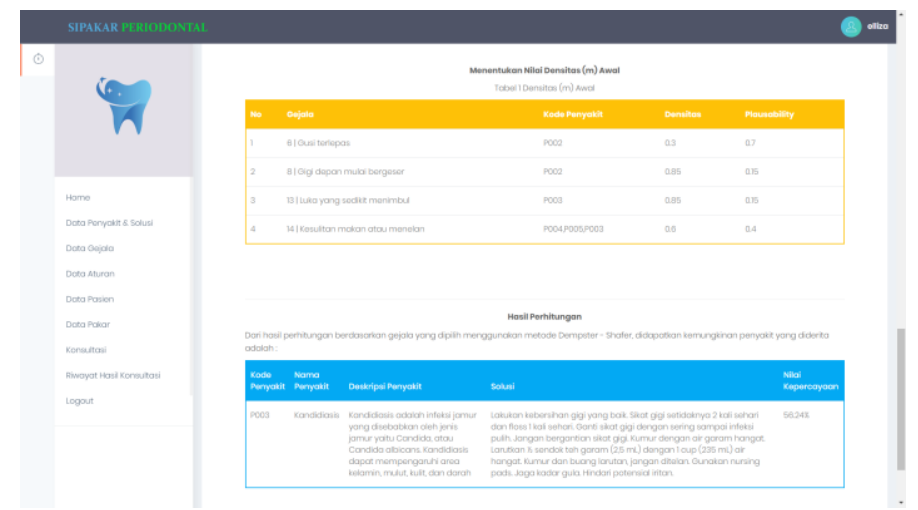

Gambar 8. Halaman Hasil Konsultasi

Halaman hasil konsultasi merupakan halaman yang menampilkan hasil konsultasi dari sistem berdasarkan gejala yang telah dipilih oleh pasien. Hasil konsultasi akan menampilkan jenis penyakit yang sedang diderita oleh pasien, definisi penyakit, solusi yang dapat dilakukan serta nilai kepercayaan sistem terhadap hasil diagnosa.

Nilai kepercayaan dihasilkan dari perhitungan metode Dempster - Shafer berdasarkan nilai densitas gejala yang telah dipilih. Pada gambar tersebut, pasien memilih 4 gejala yaitu, Gusi terlepas, Gigi depan mulai bergeser, Luka yang sedikit menimbul, dan Kesulitan makan atau minum. Nilai densitas berasal dari nilai belief yang ditambahkan pada basis pengetahuan.

\subsection{Hasil Uji Fungsi Sistem}

\subsubsection{Pengujian Aplikasi}

Tabel 5. Hasil Pengujian Aplikasi

\begin{tabular}{|c|l|c|}
\hline \multicolumn{1}{|c|}{ No } & Status \\
\hline 1 & User memilih gejala & Valid \\
\hline 2 & Menampilkan hasil diagnosa penyakit & Valid \\
\hline 3 & Login menggunakan username dan password pasien & Valid \\
\hline 4 & Login menggunakan username dan password dokter & Valid \\
\hline 5 & Login menggunakan username dan password pakar & Valid \\
\hline 6 & Login menggunakan username dan password administrator & Valid \\
\hline 7 & Input, Edit, Delete data penyakit & Valid \\
\hline 8 & Input, Edit, Delete data gejala & Valid \\
\hline 9 & Input, Edit, Delete data aturan & Valid \\
\hline
\end{tabular}

Berdasarkan hasil pengujian setiap modul aplikasi, didapatkan bahwa sistem yang dibuat telah berjalan dengan normal dan sesuai dengan rancangan yang dibuat.

\subsubsection{Hasil Uji Keakuratan Sistem}

Pengujian keakuratan aplikasi dalam mendiagnosa penyakit dilakukan dengan membandingkan hasil diagnosa keluaran sistem dengan hasil diagnosa oleh dokter. Pengujian dilakukan terhadap 14 orang pasien yang berkunjung pada klinik gigi dan mulut rumah sakit umum langsa. Adapun hasil pengujian disajikan pada tabel berikut: 
Tabel 6. Hasil Uji Keakuratan Sistem

\begin{tabular}{lcccc}
\hline \multicolumn{1}{c}{$\begin{array}{c}\text { Nama } \\
\text { Pasien }\end{array}$} & Diagnosa Sistem & Persentase & Diagnosa Dokter & $\begin{array}{c}\text { Kesesuaian } \\
\text { Diagnosa }\end{array}$ \\
\hline Ani & Kandidiasis & $56,24 \%$ & Gingivitis & Tidak Sesuai \\
\hline $\begin{array}{l}\text { Neysa } \\
\text { Ufaira }\end{array}$ & Periodontitis & $99,79 \%$ & Periodontitis & Sesuai \\
\hline Ir. Irawan & Abses Periodontal & $72,97 \%$ & Abses Periodontal & Sesuai \\
\hline $\begin{array}{l}\text { Intan } \\
\text { Purnama } \\
\text { Sari }\end{array}$ & Gingivitis & $79,13 \%$ & Gingivitis & Sesuai \\
\hline $\begin{array}{l}\text { Zahari } \\
\text { Yahya }\end{array}$ & Gingivitis & $76,27 \%$ & Gingivitis & Sesuai \\
\hline Evi Zulida & Periodontitis & $94,11 \%$ & Periodontitis & Sesuai \\
\hline $\begin{array}{l}\text { Ayu Mustika } \\
\text { Sari }\end{array}$ & Abses Periapikal & $53,52 \%$ & Abses Periapikal & Sesuai \\
\hline Irfan Taufiq & Gingivitis & $72,74 \%$ & Gingivitis & Sesuai \\
\hline $\begin{array}{l}\text { Diman Sari } \\
\text { Siregar }\end{array}$ & Gingivostomatitis & $95,28 \%$ & Gingivostomatitis & Sesuai \\
\hline Fatimah & Periodontitis & $93,16 \%$ & Periodontitis & Sesuai \\
\hline $\begin{array}{l}\text { Fachrul } \\
\text { Rizza }\end{array}$ & Periodontitis & $65,73 \%$ & Periodontitis & Sesuai \\
\hline Tukiman & Abses Periapikal & $87,56 \%$ & Abses Periapikal & Sesuai \\
\hline Handayani & Periodontitis & $99,87 \%$ & Periodontitis & Sesuai \\
\hline Cut Nasliah & Abses Periodontal & $77,15 \%$ & Abses Periodontal & Sesuai \\
\hline & & & Jumlah Data Sesuai & 13 \\
\hline & & & Jumlah Data Tidak Sesuai & 1 \\
\hline & & & Jumlah Data & 14 \\
\hline Adapun perat & & & & \\
\hline
\end{tabular}

Adapun perhitungan perbandingan antara diagnosa sistem dengan diagnosa dokter adalah sebagai berikut:

Nilai akurasi sesuai:

$$
\begin{aligned}
& =\frac{\text { Jumlah data }- \text { Jumlah data tidak sesuai }}{\text { Jumlah data }} \times 100 \% \\
& =\frac{14-1}{14} \times 100 \% \\
& =92,86 \%
\end{aligned}
$$

Nilai akurasi tidak sesuai:

$$
\begin{aligned}
& =\frac{\text { Jumlah data }- \text { Jumlah data sesuai }}{\text { Jumlah data }} \times 100 \% \\
& =\frac{14-13}{14} \times 100 \% \\
& =7,14 \%
\end{aligned}
$$

Berdasarkan uji keakuratan terhadap hasil diagnosa sistem didapatkan nilai keakuratan sebesar $92,86 \%$, sedangkan nilai ketidak akuratan sebesar 7,14\%. Sistem pakar diagnosa penyakit periodontal metode Dempster - Shafer mampu mendiagnosa penyakit periodontal secara valid karena memiliki nilai keakuratan sebesar $92,86 \%$.

\section{KESIMPULAN}


Berdasarkan hasil pengembangan dan penelitian terhadap sistem pakar diagnosa penyakit periodontal menggunakan metode Dempster - Shafer yang telah peneliti lakukan, dapat disimpulkan bahwa:

1. Sistem Pakar Diagnosa Penyakit Periodontal Menggunakan Metode Dempster - Shafer mampu digunakan sebagai media diagnosa penyakit periodontal secara valid karena aplikasi ini memberikan hasil diagnosa dengan nilai keakuratan sebesar 92,86\% dan telah diuji terhadap 14 orang pasien klinik gigi dan mulut rumah sakit umum daerah langsa tanpa terjadi kegagalan fungsi sistem.

2. Pengembangan sistem telah berhasil dilakukan karena sistem pakar telah berjalan dan berfungsi secara normal serta sesuai dengan rancangan yang telah dibuat.

\section{DAFTAR PUSTAKA}

[1] Afyenni, Rita, 2014. Perancangan Data Flow Diagram Untuk Sistem Informasi Sekolah (Studi Kasus Pada Sma Pembangunan Laboratorium UNP). Jurnal TEKNOIF. 2(1): 35-39

[2] Hamidi, Ricky, Hengky Anra, Helen Sasty Pratiwi. 2017. Analisis Perbandingan Sistem Pakar Dengan Metode Certainty Factor Dan Metode Dempster-Shafer Pada Penyakit Kelinci. Jurnal Sistem dan Teknologi Informasi (JUSTIN). 5(2): 142-147.

[3] Hatta, Muhammad. 2011. Penyakit Periodontal Dan Hubungannya Dengan Aterosklerosis. Fakultas Kedokteran Gigi. Universitas Hasanuddin Makassar

[4] Kemenkes Ri. 2013. Riset Kesehatan Dasar; RISKESDAS. Jakarta: Balitbang Kemenkes Ri

[5] Kirman, Andika Saputra, Jacky Sukmana. 2019. Sistem Pakar Untuk Mendiagnosis Penyakit Lambung Dan Penanganannya Menggunakan Metode Dempster Shafer. Jurnal Pseudocode. 6(1): 58-66

[6] Minardi, Joko, Suyatno. 2011. Sistem Pakar Untuk Diagnosa Penyakit Kehamilan Menggunakan Metode Dempster - Shafer Dan Decision Tree. Jurnal SIMETRIS. 7(1): 83-98

[7] Nisa, Triana Dian, Rifkie Primartha. 2014. Diagnosis Penyakit Gigi Periodontal Menggunakan Sistem Pakar Fuzzy. Jurnal Generic. 9(1): 309-319

[8] Noor, Muhammad, Ayu Masykurinnisa. 2017. Aplikasi Ayatul Ahkam Berbasis Web. Jurnal Sains dan informatika. 3(2): 94-100

[9] Rosnelly, Rika. (2003). "Sistem Pakar Konsep Dan Teori”. Yogyakarta: Penerbit Andi

[10] Tampubolon, Nurmala Situmorang. 2005. Dampak Karies Gigi Dan Penyakit Periodontal Terhadap Kualitas Hidup. Makalah. Dalam: Pidato Pengukuhan Jabatan Guru Besar Tetap di Fakultas Kedokteran Gigi USU, 16 November

[11] Sembiring, Nia Sari Br, Mikha Dayan Sinaga. 2017. Penerapan Metode Dempster - Shafer Untuk Mendiagnosa Penyakit Dari Akibat Bakteri Treponema Pallidum. CSRID Journal. 9(3): 180-189

[12] Sitorus, L. 2015. Algoritma dan Pemrograman. Yogyakarta: Andi. 